\title{
Eimeria divinolimai SP. N. (APICOMPLEXA: EIMERIIDAE) IN THE RUFOUS CASIORNIS Casiornis rufus VIEILLOT, 1816 (PASSERIFORMES: TYRANNIDAE) IN BRAZIL*
}

\author{
BRUNO P. BERTO ${ }^{1}$; WALTER FLAUSINO²; ILDEMAR FERREIRA ${ }^{3}$; CARLOS WILSON G. LOPES ${ }^{2}$
}

\begin{abstract}
BERTO, B.P.; FLAUSINO, W.; FERREIRA, I.; LOPES, C.W.G. Eimeria divinolimai sp. n. (Apicomplexa: Eimeriidae) in the rufous casiornis Casiornis rufus Vieillot, 1816 (Passeriformes: Tyrannidae) in Brazil. [Eimeria divinolimi n. sp. (Apicomplexa: Eimeriidae) no caneleiro, Casiornis rufus Vieillot, 1816 (Passeriformes: Tyrannidae) no Brasil]. Revista Brasileira de Parasitologia Veterinária, v. 17, n. 1, p.33-35, 2008. Departamento de Parasitologia Animal. Instituto de Veterinária. Universidade Federal Rural do Rio de Janeiro, Km 7 da BR 465, Seropédica, RJ 23890-000, Brasil. E-mail: lopescwg@ufrrj.br

Eimeria divinolimai sp. $n$. from the rufous casiornis, Casiornis rufus (Passeriformes: Tyrannidae) was described in Brazil. Oocysts are subspherical $17.84 \pm 1.52$ by $15.90 \pm 0.99 \mu \mathrm{m}(15.61-20.00 \times 14.15-17.80)$. Shape-index (length/ width) of $1.12 \pm 0.05$ (1.01-1.20). Wall smooth and bilayered, being yellowish outer and darker inner, 2.13 $\pm 0.16 \mu \mathrm{m}(2.00-2.38)$ thick. Micropyle and residuum are absents, but one subspherical polar granule is present. Sporocysts are ovoid ranging from $14.98 \pm 0.85$ by $7.50 \pm 0.44 \mu \mathrm{m}(13.81-1619 \times 6.76-8.09)$, with smooth, thin and single-layered wall. Stieda body prominent, without substiedal body and with residuum granulated. Sporozoites with refractile body at one end.
\end{abstract}

KEY WORDS: Eimeria divinolimai, sporulated oocysts, rufous casiornis, Casiornis rufus.

\section{RESUMO}

Eimeria divinolimi sp. n. do caneleiro (Casiornis rufus) foi descrita no Brasil. Os oocistos são subsféricos medindo 17,84 $\pm 1,52$ por $15,90 \pm 0,99 \mu \mathrm{m}(15,61-20,00 \times 14,15-17,80)$. O índice morfométrico de $1,12 \pm 0,05$ (1,01-1,20). Parede do oocisto lisa e dupla, sendo a externa amarelada e a interna escura, medindo $2,13 \pm 0,16 \mu \mathrm{m}(2,00-2,38)$. A micrópila e o resíduo estão ausentes, mas um grânulo polar subesférico está presente. Os esporocistos são ovóides medindo de 14,98 \pm 0,85 por 7,50 $\pm 0,44 \mu \mathrm{m}(13,81-16,19 \times 6,76-8,09)$. A parede do esporocisto é única, lisa e fina. O corpo de Stieda é proeminente, sem corpo de substieda e com resíduo granular. Os esporozoítas com corpos refráteis em uma das extremidades.

\footnotetext{
* Supported by CNPq

${ }^{1}$ Curso de Pós-Graduação em Ciências Veterinárias, Instituto de Veterinária (IV), Universidade Federal Rural do Rio de Janeiro (UFRRJ), Km 7 da BR 465, Seropédica, RJ 23890-000, Brazil. E-mail: bertobp@ufrrj.br

2 Departamento de Parasitologia Animal, IV, UFRRJ. E-mail: flausino@ufrrj.br and lopescwg@ufrrj.br - CNPq fellowship

${ }^{3}$ Departamento de Biologia Animal, Instituto de Biologia, UFRRJ. Email: ferreira@ufrrj.br
}

PALAVRAS-CHAVE: Eimeria divinolimai, oocistos esporulados, caneleiro, Casiornis rufus.

\section{INTRODUCTION}

The rufous casiornis, Casiornis rufus Vieillot, 1816 is a native bird of South America. It is a tyrant flycatcher, adapted to dry forest and edge habitats where it is usually found in pairs (SMITH, 2007).

This species has a large range of $2,800,000 \mathrm{~km}^{2}$. Its global distribution is limited to the countries of Argentina, Bolivia, Brazil, Paraguay, Peru and Uruguay. (BIRD LIFE INTERNATIONAL, 2007).

Coccidiosis in Passeriformes is rare when associated to parasites of the genus Eimeria. Only six species are recognized by Duszynski and Couch (2004). The objective of this paper was to describe a new species E. divinolimai from the rufous casiornis, C. rufus from Brazil.

\section{MATERIAL AND METHODS}

\section{Samples}

Fecal samples from two free range $R$. casiornis were collected at Três Marias dame in the State of Minas Gerais 
and they were placed into plastic vials containing potassium dichromate solution $\left(\mathrm{K}_{2} \mathrm{Cr}_{2} \mathrm{O}_{7}\right)$ at $2.5 \% 1: 6 \mathrm{v} / \mathrm{v}$ and transported to Laboratório de Coccídios and Coccidioses, Projeto Sanidade Animal (Embrapa/UFRRJ), Departamento de Parasitologia Animal, Instituto de Veterinária from Universidade Federal Rural do Rio de Janeiro. To take place the sporulation process, the fecal material was filtrated with double gauze and placed on Petri dishes at room temperature $\left(23-28^{\circ} \mathrm{C}\right)$ for ten days until most oocysts are sporulated, $70 \%$ approximately. Oocysts were recovered from the fecal samples by using saturated sugar flotation technique according Duszinski and Wilber (1997).

\section{Morphology}

Morphological observations and measurements were performed by using a binocular microscope Carl Zeiss with apochromatic oil immersion objective and ocular micrometer K-15X PZO (Poland). Line drawings were prepared with a binocular microscope Wild M-20 (Suisse) with drawing tube.

\section{Photographies}

Pictures were prepared by using a digital camera model CD Mavica MVC-CD250 (Sony ${ }^{\circledR}$, Japan) and a photographic camera f-KAS Automatic-2 in a triocular microscopy (Zeiss Jena, formely Democratic Republic of Germany) with films ISO 100 (21 DINA) (Kodak, Mexico).

\section{RESULTS}

Eimeria divinolimai n. sp.

\section{Description}

Oocysts (Figures 1 and 2) are subspherical $17.84 \pm 1.52$ by $15.90 \pm 0.99 \mu \mathrm{m}(15.61-20.00 \times 14.15-17.80)$. Shape-index (length/ width) of $1.12 \pm 0.05$ (1.01-1.20). Wall smooth and bilayered, being yellowish outer and darker inner, $2.13 \pm 0.16$ $\mu \mathrm{m}$ (2.00-2.38) thick. Micropyle and residuum are absents, but one subspherical polar granule is present. Sporocysts are ovoid $14.98 \pm 0.85$ by $7.50 \pm 0.44 \mu \mathrm{m}(13.81-16.19 \times 6.76-$

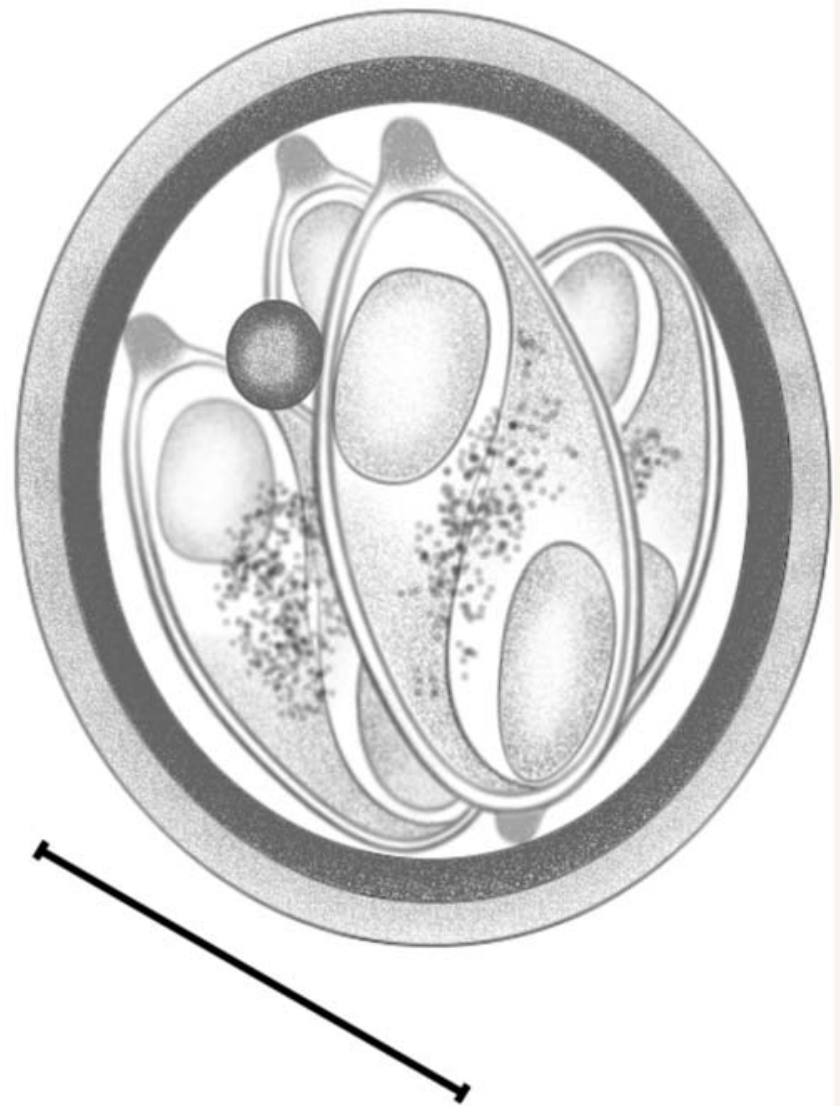

Figure 1. Eimeria divinolimai n. sp. from Casiornis rufus. Sporulated oocyst. Line draw. $(-=10 \mu \mathrm{m})$

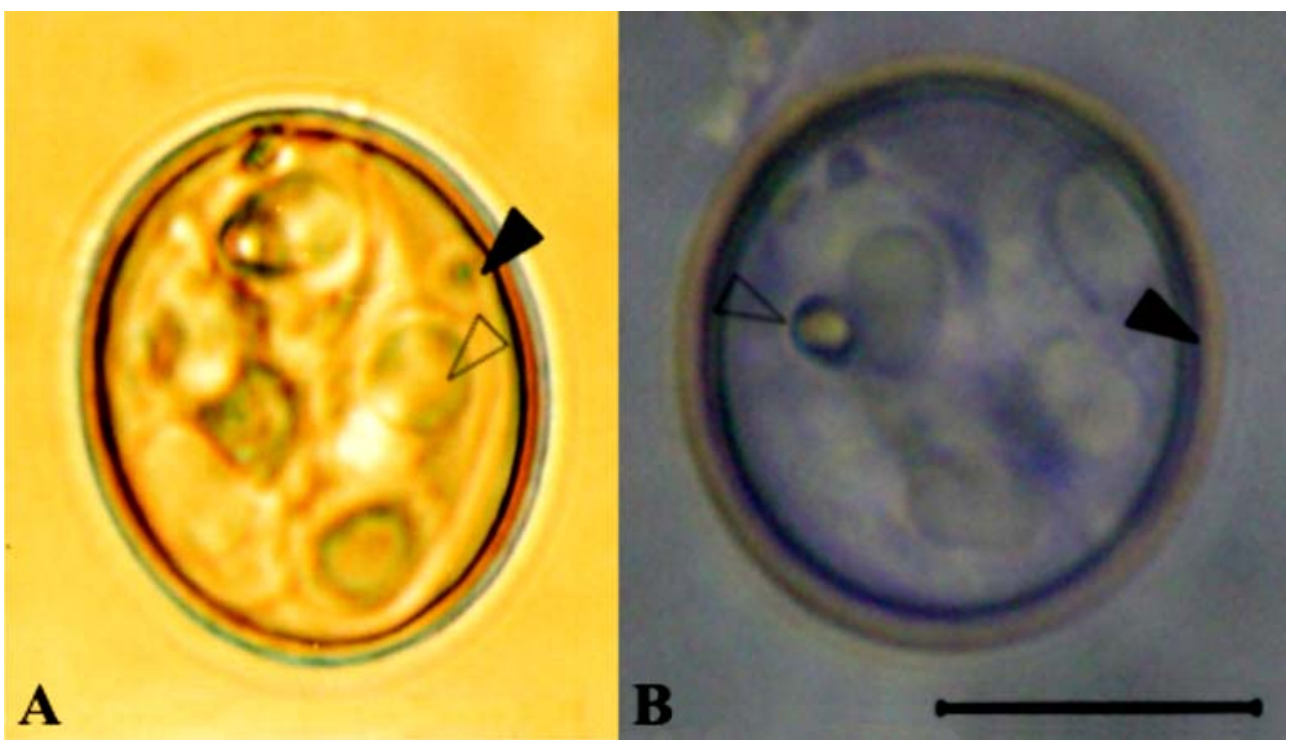

Figure 2. Eimeria divinolimai n. sp. from Casiornis rufus. Sporulated oocysts. A. Sporocysts with Stieda body prominent (dark arrowed) and sporozoites with refractile body at one end (empty arrowed). B. Oocyst polar granule (empty arrowhead) and wall smooth and bilayered, being yellowish outer and darker inner (dark arrowhead). Saturated sugar solution. $(-=10 \mu \mathrm{m})$ 
8.09), with smooth, thin and single-layered wall. Stieda body prominent, without Substiedal body and with residuum granulated. Sporozoites with refractile body at one end.

\section{Taxonomic summary}

Type host: the rufous casiornis, Casiornis rufus (Passeriformes: Tyrannidae).

Type material: oocysts in 10\% formaldehyde-saline solution deposited at the Parasitology Collection, in the Department of Animal Parasitology, UFRRJ, Seropédica, State of Rio de Janeiro, Brazil. Repository number is P-12/2007, including phototypes and line drawings.

Type Locality: Três Marias, Minas Gerais, Brazil.

Site of infection: unknown, oocysts recovered from feces.

Etymology: The specific name is derived from the family name of a Brazilian parasitologist Dr. José Divino Lima.

\section{DISCUSSION}

The descriptions of the genus Eimeria in Passeriformes order are scarce. Only six species were described and none of them in the family Tyrannidae, where C. rufus is inserted. Moreover, of all hosts birds whose descriptions had been made only the common starling Sturnus vulgaris (Sturnidae) which is sympatric of the C. rufus (DUSZYNSKI; COUCH, 2004), in which was described E. balozeti Yakimoff and Gousseff (1938). The oocysts are larger (19.52-30.60 x 17.08-26.60 $\mu \mathrm{m})$ from those described in this paper and they do not present polar granule.

Eimeria anili was described by Haldar et al. (1982), from Asian pied starling, S. contra (Sturnidae). It is differentiated, mainly, for presenting micropyle. Eimeria depuytoraci Cerná (1976) was described from Garden warbler Sylvia borin and in the lesser whitethroat, S. curruca (Sylviidae) in Prague. The oocysts are single-layered and their sporocysts are smaller $(8 \times 9 \mu \mathrm{m})$.

Eimeria malaccae Chakravarty and Kar (1944) was described from Chestnut munia, Lonchura malacca (Estrildidae) and E. paradisaeai Varghese (1977) was described from count raggi's bird of Paradise Paradisaea raggiana (Paradisaeidae), and E. saubenovae Dzerzhinskii and Kairullaev (1989) was described from Red-backed shrike Lanius collurio (Laniidae). The oocysts of these species are larger in size and were different from those described in this paper.

All species described were observed out from the American continent and despite of geographic separation E. divinolimai sp. n. was reported herein becomes the first species of Eimeria described from birds of the family Tyrannidae.

\section{REFERENCES}

BIRD LIFE INTERNATIONAL. Species factsheet: Casiornis rufus, 2007. Available on: <http://www.birdlife.org>. Access: 24 may. 2007.

CERNA, Z. Two new coccidians from passeriform birds. Folia Parasitologica, v. 23, n. 3, p. 277-279, 1976.

CHAKRAVARTY, M.; KAR, A.B. Studies on the coccidia of Indian birds II. Observations on several species of coccidia of the subfamilies Cyclosporinae and Eimeriinae. Proceedings of the Indian Academy of Science, v. 20, p. 102-114, 1944.

DUSZYNSKI, D.W.; COUCH, L. The coccidia of Passeriformes (Eimeria), 2004. Available on: <http:// www.k-state.edu/parasitology/worldcoccidia $>$. Access: 24 may. 2007.

DUSZYNSKI, D.W.; WILBER, P.G. A guideline for the preparation of species descriptions in the Eimeriidae. Journal of Parasitology., v. 83, n. 2, p. 333-336, 1997.

DZERZHINSKII, V.A.; KAIRULLAEV, K.K. Coccidia from wild animals in lower region of the river Turgai. Izvestiya Akademia Nauk Kazachskoi SSR, seriya Biologicheskaia Nauk, v. 2, n. 1, p. 30-34, 1989.

HALDAR, D.P.; RAY, S.K.; MANDAL, R.K. A new coccidium, Eimeria anili n. sp. from an Indian passerine bird. Archiv fur Protistenkunde, v. 126, n. 2, p. 217-219, 1982.

SMITH, P. Fauna Paraguay. Rufous casiornis Casiornis rufus. Available on: <http://www.faunaparaguay.com/>. Access: 24 may. 2007.

VARGHESE, T. Eimeria paradisaeai sp. n. and Isospora raggianai $\mathrm{sp}$. $\mathrm{n}$. from the Raggiana birds of paradise (Paradisaea raggiana sclater) from Papua New Guinea. Journal of Parasitology, v. 63, n. 5, p. 887-889, 1977.

YAKIMOFF, W.L.; GOUSSEFF, W.F. Eimeria balozeti n. sp., coccidie nouvelle de Sturnus vulgaris. Archives de l'Institut Pasteur de Tunis, v. 27, p. 282-283, 1938.

Received on June 21, 2007.

Accepted for publication on December 16, 2007. 